\title{
AN AGGLOMERATION BENEFITS OF OIL AND GAS FIRMS: AN EXPLORATORY STUDY THROUGH INDUSTRIAL CLUSTER
}

\author{
Maryam Kalhoro \\ Lecturer Business Administration, Sindh University Larkana Campus \\ Email:maryam@usindh.edu.pk \\ Dahshila Junejo \\ Assistant Professor Commerce, Sindh University Mirpurkhas Campus \\ Email:dahshilla@usindh.edu.pk \\ Dr.Sanobar Salman Shaikh \\ Assistant Professor Institute of Business Administration, University of Sindh \\ Email:sanobershaikh25@yahoo.com
}

\begin{abstract}
The research investigates the agglomeration pattern of seven national, international oil and gas extraction and production companies through an exploration of oil and gas cluster components and subcomponents. For this exploratory study, data is collected through primary sources via in-depth interviews from managers of national and international oil and gas MNCs working in Sindh, Pakistan and through secondary sources of business reports. The content analysis is adopted to analyze the data. Results of this study reveal that there is strong existence of exploration and production companies which results in agglomeration, however, other components of oil and gas cluster like refineries, marketing companies, supporting institutes, media and government poorly exist in Sindh province of Pakistan. Findings also highlight that the Sindh as a resource-rich region is still underdeveloped due to poor management of resources or because of the absence of ideal oil and gas cluster components and coordination among them in the region.
\end{abstract}

Keywords: Agglomeration, Oil and Gas sector, cluster components, regional development Sindh, Pakistan.

\section{INTRODUCTION}

Pakistan is rich in oil and gas reserves that can sufficiently help to accelerate the economic growth of the country (Haque and Arif, 2007). According to Akbar (2005), Pakistan is the country which mainly depends on oil and gas resources for their energy consumption. Since the 1980s, the country's crude oil consumption is greater than the production. The average crude oil production in the year 2013 is 51.32 , and its consumption is 285.38 barrels per day, respectively 
(Bhutto et al., 2017). Government of Pakistan tries to introduce new policies for oil and gas companies, trade and foreign direct investment in this sector to meet the energy demand in future.

Sindh is the largest gas-producing province of Pakistan, and it contributes more than 70 per cent gas of total production in the country (Tirmizi, 2017). However, Sindh being the richest province in terms of natural resources is in contradiction with the issues of poverty, unemployment, malnutrition, health disease, shortage of CNG and LNG, load shedding of gas, and a shortage of petroleum that it faces. Despite this lamentable situation, our policymakers' role is restricted to silent spectators (Bhutto et.al., 2017).

Besides agglomeration policy, an idea for institutions is also needed to develop an autonomous cluster conceptualization. Jianyi et.al., (2019) stated that the institutions are the structures following rules and procedures which present the relations and interactions by facilitating and limiting the decisions of negotiators. Informal institutions are not based on any written norms and values, whereas formal institutions are followed by certain policies, laws and regulations (Irina, 2020).

Industrial clusters are defined by Edward et.al., (2020) as "geographic agglomeration of companies, suppliers, service providers, and associated institutions in a particular field". Clusters are an empirical reality and recognized as a central part of modern economic industrialization and regional development (Porter, 1998; Grabher, 1993; Loasby, 1999; Amin and Cohendet, 1999; Maskel, 2001; Belussi and Pilotti, 2002; Lombardi, 2000; Sorenson, 2005 and Belussi 2015). Agglomeration economies represent clusters as an activity that boost the productivity of the firms through two sources of such gain. First is in localization economy in which firm benefits from the proximity (Marshall, 1890). Second is in urbanization economies in which firm benefits from diversity among the industry and overall local urban size (Henderson et.al., 1995).

According to Bembenek (2015), in cluster concept, the institutional dimension's significance fall in two perspectives includes (i) the institution is an important determinant, which supports the performance of the clusters by reducing uncertainty, enlightening several national as well as global development paths; and (ii) a cluster, as the inter-organizational localized network, itself is a structure of 
institutional arrangement (Bembenek, 2015). Importantly, different industries have their regional concentrations in different locations, and diverse regions specialize in different industries. Cluster formation reflects the existence of spillovers and linkages between companies. These externalities construct real economic value. Companies can achieve higher levels of productivity and employment because they have close access to specialized suppliers and service providers, technology advancement and can rapidly learn from the best practices of close competitors (Ketels, 2007).

The policymakers and researchers have emphasized the clusterbased approach for socio-economic development of the region. According to Jianyi et.al., (2019), industrial clusters emerge where the business environment provides opportunities for individual companies to conduct profitable operations. But then it almost always requires a strong general business environment to move from individual companies to a sustained agglomeration process in which more and more companies are attracted.

This study aims to explore such issues in-depth and to understand the agglomeration benefits of oil and gas firm's contribution to regional development. This research argues that the development policies in the context of the industrial clusters, the business environment and the governance structure is required for sustained oil and gas clusters which can improve the socio-economic conditions of the region (Kalhoro et.al., 2017; Luguang, 2019). The research aims to investigate the agglomeration pattern of oil and gas firms through an exploration of existence and non-existence of oil and gas cluster components and subcomponents that contribute towards economic performance in Sindh.

The paper consists of six sections. The first section is based on the brief history of the oil and gas industry and literature review of the study. It starts with a general discussion of the geographic agglomeration towards the oil and gas industry with industrial clusters importance in the particular region. The second section discusses the definition of oil and gas cluster that emerges from the analysis of actual co-location patterns in Norway and Kazakhstan. The third section presents the empirical analysis for exploring oil and gas cluster components and sub-components in Sindh. The fourth section is based 
on a precise discussion of research on oil and gas clusters in a particular region. The last section concludes the research briefly.

\section{LITERATURE REVIEW}

This section contributes to the literature review deals with industrial clusters, their different types and components. This section also covers the literature on regional economic development through industrial clusters.

The paradigm of the industrial cluster was initially raised by Alfred Marshall on localized industries and industrial districts theory. Plyaskina (2017) provide the evidence from (Audretsch and Feldman 1996; Pouder and St. John and Pouder 1999; Klepper, 2007) that companies in clusters can grow stronger and more modernize than non-clustered firms. Industrial cluster as a portrait by (Porter, 2000) a group of interconnected companies working within geographical boundaries including services provider, different material supplier, related firms, other supporting institutions like government bodies, universities and trade association and are also complementary with each other (Ivanenko, 2019).

In the context of developing countries, diverse types of industrial clusters are highlighted, which are also different from the industrial clusters in developed countries. The types industrial cluster is embodied in differences like a "dormant cluster" which means service to the poor customer and producing low-income procedures of employment, other is a dynamic cluster, which is a close network firm which can compete in world markets (Sandee, 1999). The incipient cluster is in the early phase of industrial growth which is low-income areas using simple technologies and low-income labour. Still, a mature cluster which can compete in global markets, using of advance manufacture technology needs more refined labour skills (Schmitz and Nadvi, 1999). These types of clusters play a significant role in sustainability in terms of productivity, infrastructure, job creation, reduces poverty in developing counties.

Internal and external forces influence industrial clusters. They comprise of different interacting components, like companies and institutions, i.e., suppliers, collaborators, competitors, customers, academia, research council, training and education institutions (Fornahl, 2015). Institutions refer to as forms of educational, research, networking or financial organizations which are the premise for 
knowledge creation in a cluster also that cluster impact on society in the region. The existence of the industrial cluster, thus, is dependent on the co-location of interconnected firms and institutions that share technological proximity, easier access to internal and external information and a common technological understanding and trust.

The geographic agglomeration of economic activities is significantly related to regional economic development in a country (Hohenberg and Lees, 1985; Boschma and Frenken, 2011a; Fornahl et.al., 2015). The function of cities in economic progress and technological growth is emphasized by urban economists (Henderson, 1988; Fujita and Thisse, 1996; Terstriep and Lüthje, 2018), development economists (Williamson, 1988) as well as by economists of growth (Lucas, 1988). Fujita and Thisse (2002b) conclude that "agglomeration can be thought as the territorial counterpart of economic development". It is evident from different studies (Jacobs, 1969; Jaffe et al., 1993; Coe and Helpman, 1995 and 1997; Ciccone and Hall, 1996 and Fang, 2015) that technology spillovers are not entirely localized nationally as well as globally.

\section{A CASE STUDY: OIL AND GAS SECTOR, SINDH PAKISTAN}

This section is about the case study of the oil and gas sector in Sindh, Pakistan. The brief history, facts and figures of oil and gas exploration, production and consumption in Sindh province and country-wise is provided. The standard oil and gas cluster is also presented by using the mapping process introduced by Porter (2001).

Oil and Gas Sector in Pakistan: Historical Perspective: According to MoPNR (2018), Pakistan petroleum industry has played a significant role in the national economic development by exploring large indigenous oil and gas resources since independence. Pakistan is the country which mainly depends on oil and gas resources to fulfil its energy requirement. Since the 1980s the country crude oil consumption is greater than the production, the average crude oil production and consumption from 1980 to 2013 is 51.32 and 285.38 barrels per day, respectively as shown in Figure 1. 


\section{FIGURE-1}

TOTAL CRUDE OIL PRODUCTION AND CONSUMPTION FROM 1980-2013 OF PAKISTAN

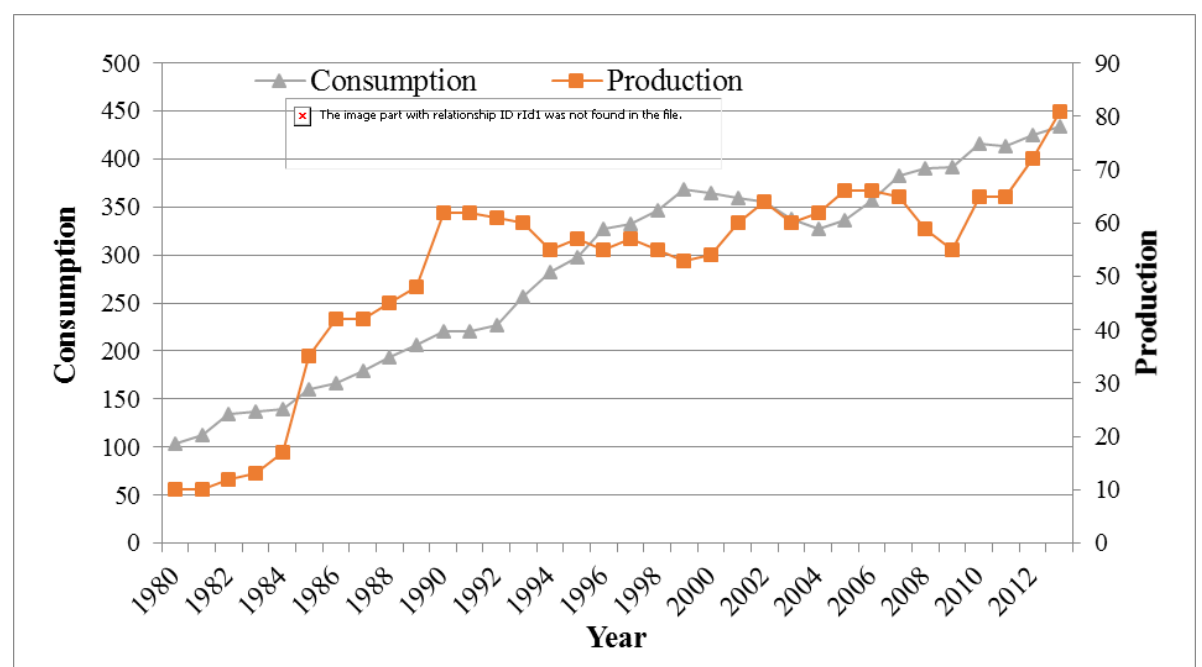

Source: Bhutto et.al., (2017).

In Pakistan, the first well was drilled in 1866 at oil seepage Kundal in the Mianwali district of Punjab province. In 1925, Burmah Oil Company had drilled the first well at Khairpur, northern Sindh. After the exploration of Sui (Balochistan) in 1952, Sindh province remains the targeted area for oil and gas resources (Ministry of petroleum and natural resources Pakistan 2019).

Sindh contributes more than $70 \%$ of the total production of oil and gas in Pakistan (Khan et.al., 2009). The oil and gas production share from Sindh province is comparatively higher than other provinces, as shown in figure 2 below: 
FIGURE-2

OIL AND GAS PRODUCTION SHARE BY DIFFERENT PROVINCES OF PAKISTAN

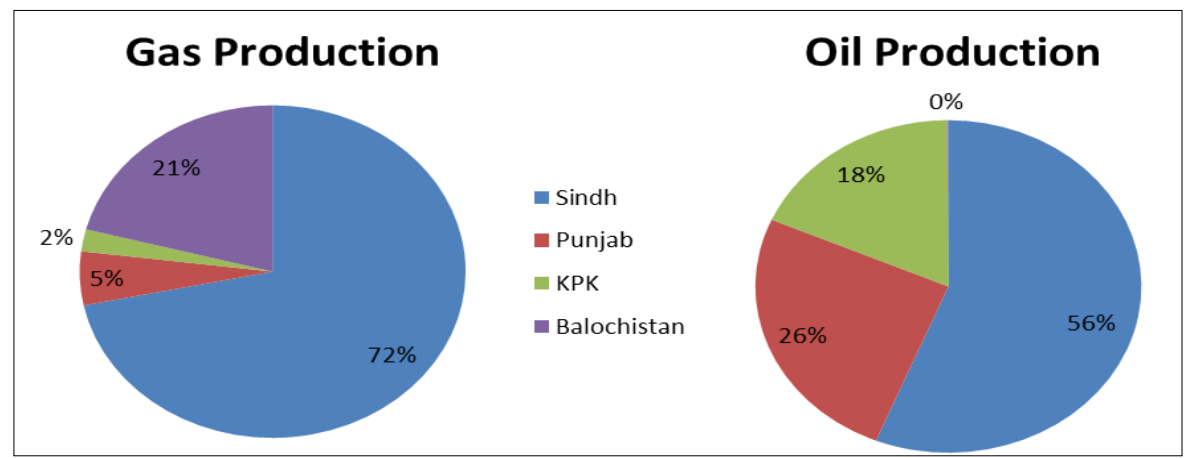

Source: OGRA, Pakistan, 2017).

Pakistan Petroleum Limited (PPL) explores gas reservoirs in different regions like Khairpur in 1957, Kandhkot in 1959 and Mazarani in1959. Pak-Stanvoc Petroleum project in 1957had discovered 6.8 trillion cubic feet oil resources in Mari and also did exploration in Talha (1957), Mirpur Bathoro (1958), Nabisar (1958) and Badin. Burmah Oil Company drilled wells in Lakhra (1958), Badro (1958-59) and Phulji- Dadu (1958). In Dadu, there are two oil and gas fields named as Zamzama and Mehar gas field. In 1961, Oil and Gas Development Corporation was established, which discovered gas at Sari (1966), Kothar (1973) and Hundi (1977). District Sanghar has 39 million cubic feet of gas reserves have been discovered. District Sanghar is considered Pakistan second-largest oil and gas producing field which produces 2,100 barrels per day of condensate and 11.05 million cubic feet per day (MMCFD) of natural gas (Pakistan Association of Petroleum and Geosciences (PAPG), 2019). OGDCL has explored the shale gas and tight oil deposits in the potential areas of Sindh with new reserves. The authorities claim the presence of 95 Trillion Cubic Feet (TCF) shale gas and 14 billion of stock tank barrels (BSTB) oil in Sindh region. The gas reserves are enough to fulfil the country's needs for 90 years.

Qadirpur gas field in Ghotki is a third-largest gas-producing field with 3.6 trillion cubic feet with production from 36 out of total 45 drilled wells ranges from 600 to 700 million cubic feet of gas per day. 
Sawan gas field, one of Pakistan's largest gas reserves, is also in Sindh. In Sawan field, 14 out of total 15 drilled wells are supplying $270 \times 106$ cu ft $\left(7,600,000 \mathrm{~m}^{3}\right) \mathrm{d}$ gas to Sui Northern Gas Pipelines and 40×106 cu ft $\left(1,100,000 \mathrm{~m}^{3}\right) \mathrm{d}$ to Sui Southern Gas Company (MoPNR, 2019). Ministry of petroleum and natural resources in Pakistan, 2019).

The oil and gas sector include exploration, production, refining, distribution and transportation (tankers and pipelines), and marketing petroleum products. The largest production of Pakistan oil and gas industry is fuel oil, gasoline (petrol) and natural gas (Pakistan oil and gas policy division, World Bank document, 2013). The Petroleum Concession Director-General Imran Ahmed had told the senate standing committee that the total oil and gas production in the country for the year 2018-2019 is 89,030 BOPD (barrels of oil per day) and 3, 935 MNCFD (thousand cubic feet per day).

Current Structure of the Oil and Gas Sector: The Pakistan oil and gas sector's current structure are divided into three major industries: upstream, midstream and downstream. The upstream industry is based on exploration and production (E\&P) companies involve in the survey and drill the underground and underwater crude oil. There are about eleven oil and gas companies working in Pakistan, namely OGDCL, PPL, MPCL, ENI, BHP Ltd, MOL, OMV/UEP, DEEWAN, POL, OPPL and OPL. The operating company's function is to drill the wells on the sites and involve in oil and gas production. The service companies are those who are responsible for providing seismic data about the presence of hydrocarbons to the investor companies. Since 2015 companies are trying to establish their units at the head offices to create their services. Upstream industries also involve in stabilization process of crude oil and separate the natural gas and petrol at normal temperature. There are about four international services companies named as Halliburton, Weatherford, Schlumberger and Sprint outsourcing their expert teams to Pakistan for seismic data field survey. Since 2017, national companies like OGDCL, PPL and MPCL has established their seismic service units at Islamabad.

Midstream industry involves in the distribution services of oil and gas products to marketing companies and refinery industry. Midstream industry provides the transportation services by rail, oil tankers, trucks and also pipelines network structure according to the 
seismic data collected. This midstream industry is considered a bridge between upstream and downstream industry. The downstream industry commonly refers to the six refineries named as PARCO Ltd., NRL, Khalifa Coastal, Indus Oil, Byco Petroleum, Attock Oil, PRL and the marketing companies i.e., SNGPL, SSGC, CALTEX, TOTAL, SHELL and PSO.

Major oil and gas exploration and production companies operating in different districts of Hyderabad, Jamshoro, Dadu, Kamber Shahdadkot, Larkana, Shikarpur, Ghotki, Sukkur, Khairpur Mirs, Kashmor Kandhkot in north region of Sindh, and Shaheed Benazirabad, Sanghar, Mirpurkhas, Thatta, Badin, Sujawal, included six districts of Karachi i.e., Malir, South, West, East, Central and Korangi are in southern or upper Sindhare shown in Figure 3.

FIGURE-3

OIL AND GAS INDUSTRY STRUCTURE IN PAKISTAN

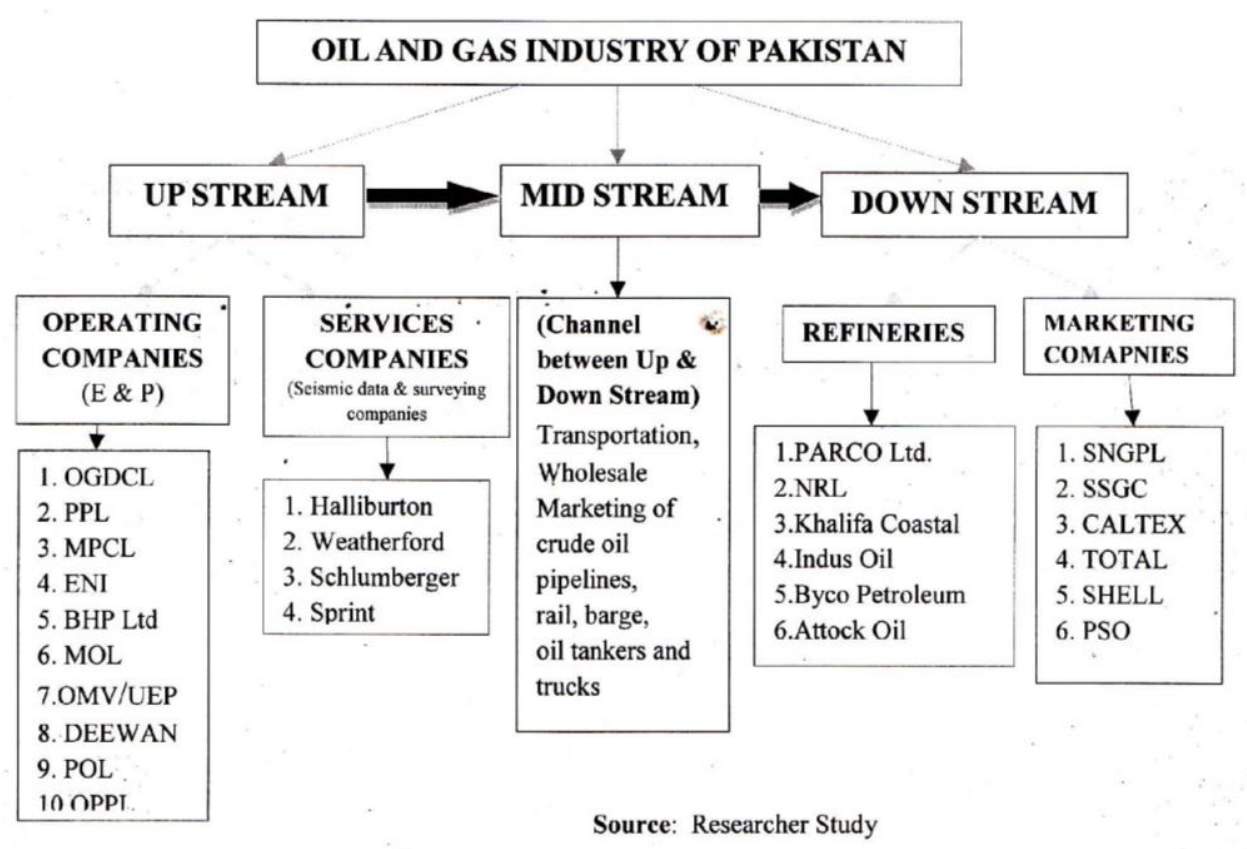

This industry distributes the finished products to the ultimate consumers. Oil and gas classification and supply chain is shown in figure 4. 
FIGURE-3

AN IDEAL OIL AND GAS INDUSTRIAL CLUSTER IN KAZAKHSTAN AND NORWAY

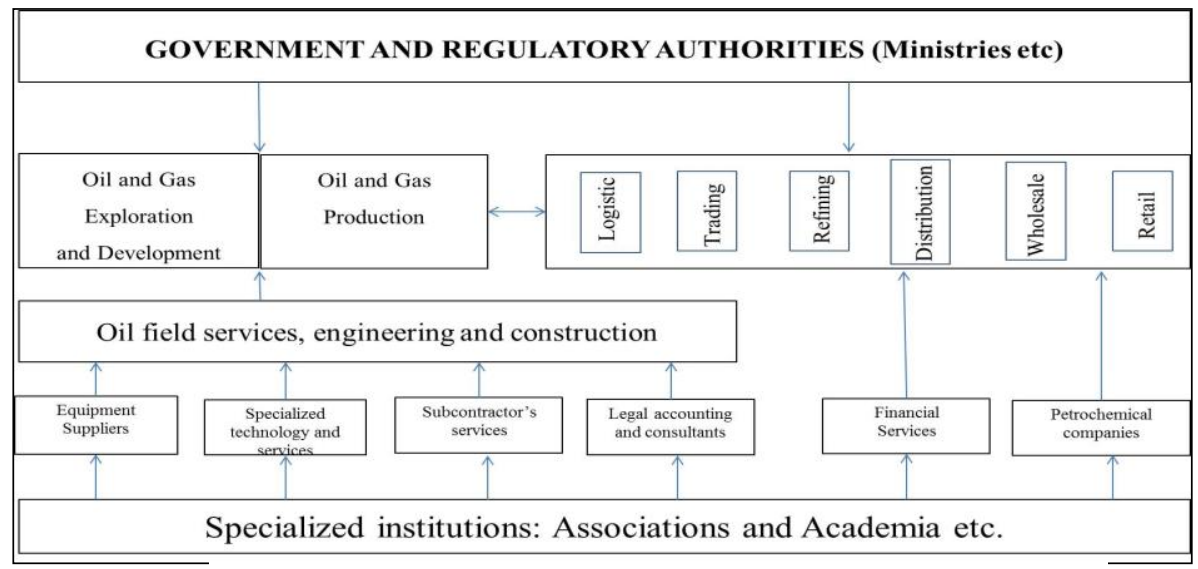

Source: Sergei Arkhipov et.al., (2010) and Olivia leskinen et.al., (2012).

Cluster Mapping and its Major Components: Porter, since (2001) has developed an empirical approach for cluster mapping to overcome weaknesses/ hindrances and create a set of cluster definitions. The ideal oil and gas industrial cluster are positively and significantly related to the regional economic development as compare to non-clustered oil and gas industry (Porter, 2003, 2007). From the literature review, Kazakhstan oil and gas cluster (Sergei Arkhipov et.al., 2010) and Norway oil and gas cluster (Olivia Leskinen et.al., 2012) are selected and simplified as an ideal industrial cluster with the presence of all major components. The cluster model consisted of different components namely oil and gas industry exploration companies, production firms, services companies, suppliers, contractors, subcontractors, government agencies, national and international financial institutions, accounting agencies, law firms, research institutes, universities, vocational, training centres and government (Figure 5). 


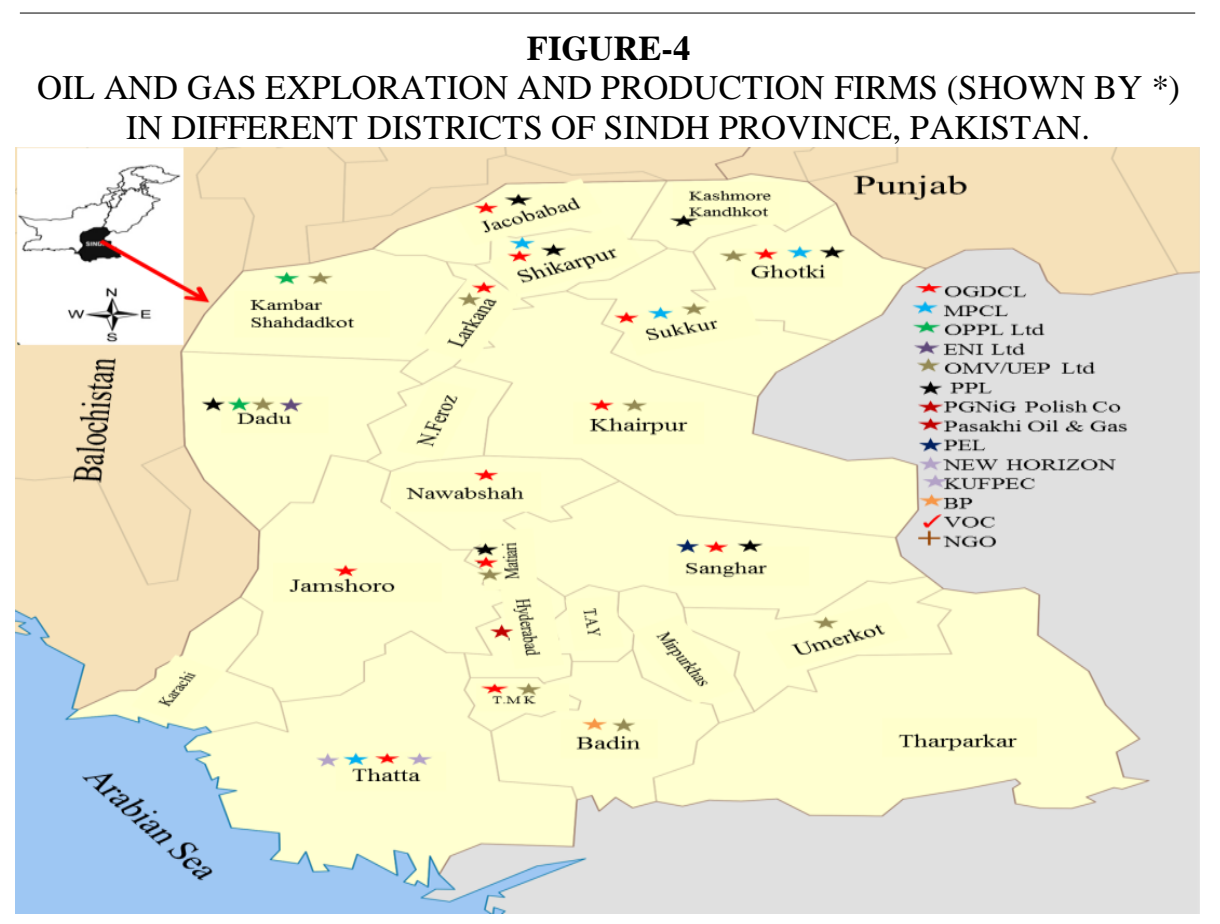

\section{RESEARCH METHODOLOGY}

The present investigation is conducted in order to explore the oil and gas clusters in Sindh. This section deals with the research design of the study based on sampling and data collection.

Sample of the Study: The sample size of the present study is oil and gas $(\mathrm{E} \& \mathrm{P})$ companies working in Sindh, Pakistan. There are eleven $\mathrm{E} \& \mathrm{P}$ companies (seven national and four international) in the oil and gas sector. Four companies (BP cufpec, OPL, PEL and New Horizon) are excluded from the analysis because of less market share and non-accessibility of the data. Seven companies, namely OGDCL, PPL, MPCL, OPPL, ENI, UEP/OMV and Polish Ltd., are finalized to collect the data from regional and field managers of $\mathrm{E}$ and $\mathrm{P}$ companies. The regional offices are located in urban cities of Sindh, i.e., Karachi, Hyderabad and Sukkur and field offices are in other different districts of Sindh.

In Sindh, about 26 out of 29 districts have oil and gas reservoirs. The data is collected from the districts which are involved in the extraction and production of oil and gas reserves while the other three 
districts namely Tharparkar, East Karachi and Korangi not involved are excluded from this study.

Data Collection: In the present study, secondary data is gathered from the company's annual reports, magazines and sustainability reports. Primary data regarding components of oil and gas cluster includes: oil and gas industry, other specialized and supporting institutions, education, training, $\mathrm{R} \& \mathrm{D}$, media networks and the government is collected from managers of regional offices and field offices of $\mathrm{E}$ and $\mathrm{P}$ companies working in Sindh. The researcher visited about ten fields in Johi, Mehar, Qamber Shehdadkot, Dahrki, Khairpur, Tando Alam, Bhit Bandra in Sehwan, Matyari, Sinjhoro and Tando Muhammad Khan and three visits to regional offices in Karachi, Hyderabad and Sukkur. The researcher also adopts the observation technique during field visits. The secondary and historical data is collected from literature review since the year 1966 to till date. Secondary data is collected from oil companies and government official websites, reports, magazines and journals of E \& $\mathrm{P}$ companies working in Sindh province.

The Agglomeration of E \& $\mathrm{P}$ companies in different districts of Sindh Province are Dadu, Kamber Shahdadkot, Larkana, Shikarpur, Jaccobadad, Ghotki, Sukkur, Khairpur Mirs, Kashmor, Kandhkot in northern/upper Sindh and Shaheed Benazirabad, Sanghar, Mirpurkhas, Thatta, Badin and districts of Karachi, i.e., Malir, South, West and Korangi in southern/lower Sindh.

Population size for this research is about eleven ( $E \& P$ ) companies working in different districts of the region. The interviews are only conducted from the regional and field managers of seven $\mathrm{E}$ and $\mathrm{P}$ companies named as OPPL, ENI, OMV/UEP, PPL, MPCL, OGDCL, PGinG Polish Co Ltd. These seven E \& P companies have huge reserves of crude oil wells in different fields of northern (upper) and southern (lower) Sindh. Regional managers of E \& P companies are mostly working in urban cities like Sukkur, Hyderabad and Karachi, whereas field officers are in a different talukas and districts of Sindh.

\section{DATA ANALYSIS}

Total seven oil and gas $\mathrm{E}$ and $\mathrm{P}$ companies (OPPL, ENI, OMV/UEP, PPL, MCPL, and OGDCL) have provided data to explore the components and sub-components of oil and gas cluster in Sindh. 
Through in-depth interview from field officers' researchers gained knowledge about oil and gas extraction and production processes, the existence of oil and gas cluster components, i.e., oil and gas industry, education, training, research and development institutes, media services and government intervention.

It is found that oil and gas clusters of Sindh region is divided into two parts, northern (upper) Sindh includes Sukkur, Larkana, Hyderabad divisions and southern (lower) Sindh consist of Mirpurkhas, Shaheed Banzairabad, Banbhore and Karachi division. In northern (upper) Sindh, Sukkur division is geographically divided into districts of Sukkur, Khairpur and Ghotki. Division Larkana is distributed into districts of Kashmor, Shikarpur, Larkana, Qamber Shehdadkot and division Hyderabad is comprising on Dadu, Hyderabad, Jamshoro, Matyari, TandoAllahyar, and Tando Muhammad Khan (T.M.K) districts. Whereas, in southern (lower) Sindh, division Mirpurkhas is divided into three districts, i.e., Mirpurkhas, Umerkot and Tharparkar. Division Shaheed Benazirabad is based on districts of Naushero Feroze, Shaheed Benazirabad and Sanghar; division Banbhore is geographically divided into the district of Badin, Sujawal and Thatta and in last Karachi division is geographically divided into five districts namely South, East, West, Korangi and Malir. Results are further discussed as under.

\section{RESULTS AND DISCUSSIONS}

This study is based on the empirical findings on the exploration of oil and gas industrial cluster in Sindh, trace back from the history of oil and gas industry which is centered on the aim of this research. The present study has analyzed that there are five major components of oil and gas cluster includes: first is oil and gas industry, second is education, training, research \& development institutions, third is specialized and supporting institutions, fourth is media services, and fifth is government agencies and have different subcomponents. The present study has identified that there are existence and non-existence of different components and subcomponents and also found the weak and strong coordination/linkages between the components of the industrial cluster.

Figure 6 shows the existence and non-existence of overall components of oil and gas clusters in northern and southern Sindh, Pakistan. In Sindh, the component and sub-components of oil and gas 
industry are more strongly exists with the percentage of $43.94 \%$ in southern (lower) Sindh, and its existence in northern Sindh is with the percentage of 35.71 (Figure 6). The sub-components of specialized and supporting institutions is found stronger in southern (lower) Sindh with $22.1 \%$. In contrast, in northern (upper) Sindh the availability of specialized and supporting institutions is found with the percentage of $14.29 \%$ (refer figure 6). It is found that there is a weak existence of media networks in northern (upper) Sindh. Only local newspaper and magazines are found in northern (upper) Sindh with 14. 29\%. However, in lower Sindh, especially in Karachi division, local journal and magazines exist at $22.1 \%$ (Figure 6). It is noted that government intervention strongly exists at the federal level. Oil and gas industry is recognized national industry, and most of the government bodies, ministries, association and commissions are physically exist at the federal level. Few government bodies exist at province level with very weak linkages to the industry.

Sindh province is producing more than $70 \%$ of oil \&gas resources, and most of the development sectors of Pakistan are using oil and gas as raw and finished products. It is realized that the reforms in the policy are required for particular provinces which can contribute towards the regional development of the country. In addition, it is recommended that oil and gas cluster components should be established at the regions/ fields where extraction and production took place to enjoy the different benefits of industrial clusters, i.e. spatial concentrations, the localized networks, availability of specialized organizations, knowledge-producing agents, bridging organizations, and government agencies to share some common underlying knowledge, resources, technology or product focus (OECD, 1999; Van den Berg,, 2001). 


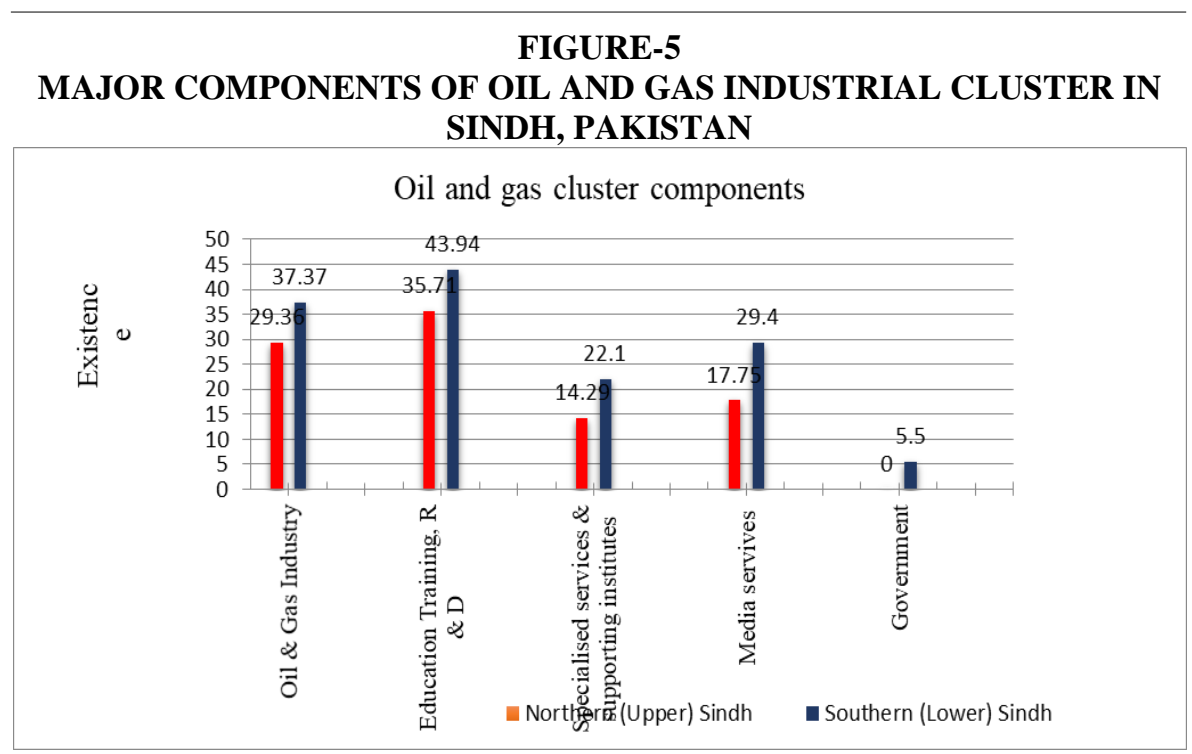

Source: Researcher study.

\section{CONCLUSION}

This research identifies that oil and gas (E \&P) companies exist in most of the districts of Sindh, Pakistan. This existence reveals that Sindh is rich in oil and gas resources which contribute towards the regional development. Different theories and studies (Porter, 1998, 2000, 2001; Schmitz and Nadvi, 1999; Lund-Thompson et.al., 2013; T. Sonobe, 2014; Gereffi, 2016; Giuliani, 2016, Knorringa and Nadvi, 2016; De Marchi et.al., 2018, Jianyi et.al., 2019) supported that presence of industries and firms in regional clusters form increases their efficiency and effectiveness which ultimately foster sustainable development in the region.

The several components of oil and gas clusters are explored in the present study from Sindh, Pakistan. The oil and gas sector scattered in the whole country Pakistan, supply chain flows from upstream industry (E and $\mathrm{P}$, services companies), midstream industry (transportation and pipelines networks services) towards the downstream (refineries and marketing companies). Pakistan is geographically divided into four provinces, i.e., Sindh, Punjab, Balochistan and KPK, most of the oil and gas reserves found in the province of Sindh. It can be viewed that the oil extraction and production process take place in Sindh province through outsourcing services. After the extraction process crude oil sent to the refineries in 
other provinces and then again supplied in the whole country to the industries and home usage.

This study identifies that there is the existence of components and subcomponents of oil and gas industrial cluster with weak linkages in northern and southern regions of Sindh. The findings reveal that some of the ideal industrial cluster's subcomponents are not physically existed, and few are existing. The existed components have their week linkages/ coordination in a cluster of the region (Figure 7). From the study, it is generalized that the component of the oil and gas industry firmly exists in Sindh province. Its subcomponents in the oil and gas upstream industry, the services companies poorly exist; however, operating companies strongly exist in the region. Collaborators poorly existed, whereas suppliers, supply chain management companies like logistics, rail, trucks, and tankers strongly exist. In the downstream sector, refineries are poorly existing whereas marketing companies strongly exist mostly in urban regions of Sindh, i.e., in Karachi, Hyderabad and Sukkur (see in Table 4,5 \& Figure 7). Another component of oil and gas cluster is education, training, $R$ and $D$ institutions. It is observed that its sub-components include: universities/ academia, training institutes, polytechnic colleges, public research laboratories are poorly existed and have weak linkages in oil and gas cluster of the region.

In figure 7 , it is also observed that vocational centers and nongovernment organizations (NGOs) strongly exist with strong linkages among each other. Another cluster component is specialized and supporting institutions. The banks are the only subcomponent which is strong exits with strong linkages whereas, all other subcomponents, i.e., auditing firms, accounting firms, international finance organizations, regulatory consultants and credit rating agencies poorly exist with weak linkages/coordination as shown in figure 7 . The subcomponents of media networks also poorly exist in the cluster but have strong linkages with the oil and gas industry in Sindh (Figure 7). Another major component of the oil and gas cluster is government. The government plays a very important role in the development of the country, but here it is observed that government bodies poorly exist with weak linkages in the oil and gas industry. The MoPNR ministry of petroleum and natural resources) is completely missing in Sindh province and has weak coordination with the oil and gas industry for 
decisions and policies. Other ministries like energy, mines and minerals, taxation, finance strongly exist in Karachi, the capital city of Sindh province but have very poor linkages with oil and gas industry in other divisions of Sindh. Other associations and commissions like oil and gas regulatory authority (OGRA) also poorly exist with very poor linkages (refer Figure 7).

FIGURE-7

MAJOR COMPONENTS OF OIL AND GAS CLUSTERS IN SINDH

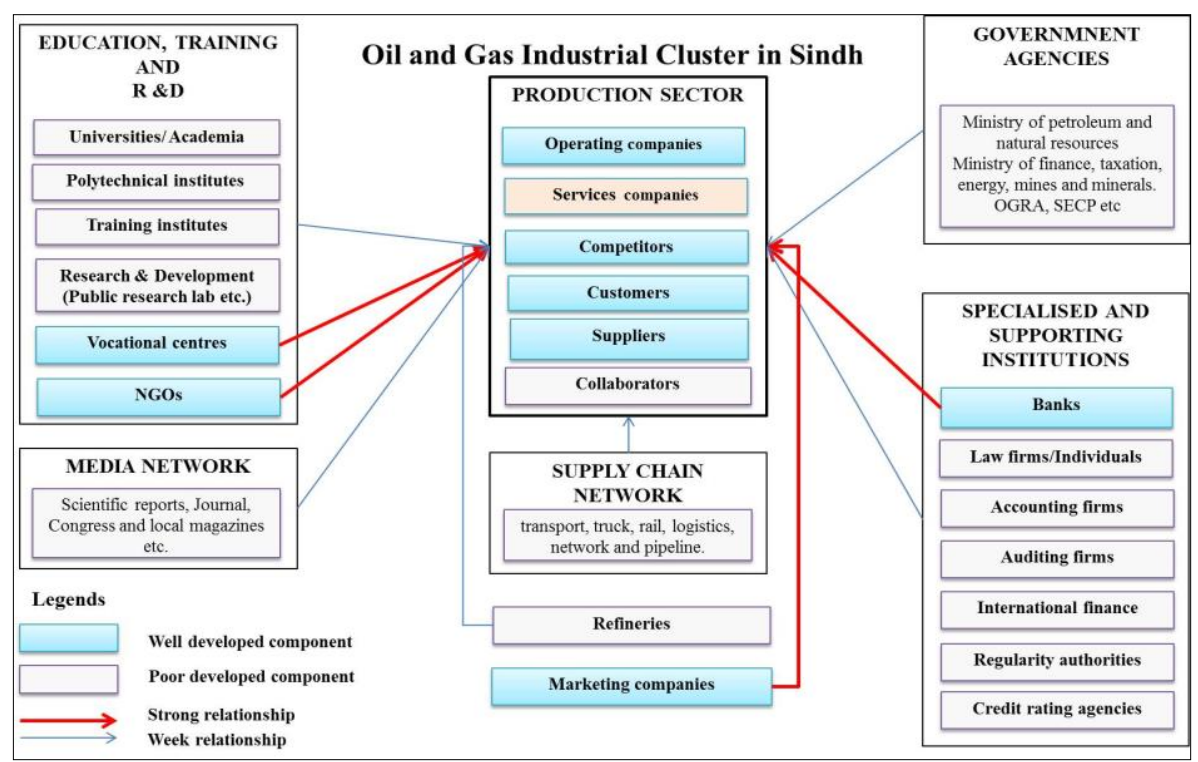

Generally, it is observed that oil and gas clusters are at the very initial / embryonic stage, and yet their members have not started to take benefits from these formations. Still, the potential and benefits are not assimilated by regions because most of the ideal cluster components of the oil and gas sector does not exist in a particular region. There is weak collaboration, knowledge sharing between the cluster components which obstruct their regional development in the context of enterprise, employment, education, health, infrastructure improvement and poverty reduction in the resource-rich region.

It is recommended that the government, oil \& gas industry and academia, media networks should take a collective step to encourage the existence of oil and gas cluster components and establish the strong linkages / knowledge sharing between all components. The 
government should review the regional policies for oil and gas industry and take effort to supplement the proposed policy of oil and gas cluster for sustainable development in the region.

\section{DECLARATION OF INTEREST STATEMENT}

No potential conflict of interest was reported by the authors.

\section{REFERENCES}

Amin, A. and Cohendet, P. (1999). "Learning and adaptation in de-centralized business networks", Environment and Planning D: Society and Space 17, 87-104

Audretsch, D.B., and A.R. Thurik. (2001). "What's new about the new economy? Sources of growth in the managed and entrepreneurial economies". Industrial and corporate change 10(1): 267-315.

Barbieri, E., Di Tommaso, M. R., \& Bonnini, S. (2012). Industrial development policies and performances in Southern China: Beyond the specialized industrial cluster program. China Economic Review, 23(3), 613-625.

Belussi, F. (2015). "The international resilience of Italian industrial districts/clusters (ID/C) between knowledge re-shoring and manufacturing off (near)-shoring." Investigaciones Regionales - Journal of Regional Research 32:89-113

Belussi, F. and L. Pilotti. (2002). Knowledge creation, learning and innovation in Italian industrial districts. Geography Annual 84: 125-139

Bergman, E. M., \& Feser, E. J. (2020). Industrial and regional clusters: concepts and comparative applications.

Bhutto, A.W., A.A. Bazmi, K. Qureshi, K. Harijan, S. Karim, and M.S. Ahmad. (2017). Forecasting the consumption of gasoline in transport sector in Pakistan based on ARIMA model. Environmental Progress \& Sustainable Energy, 36(5):1490-1497.

Chen, X., Wang, E., Miao, C., Ji, L., \& Pan, S. (2020). Industrial Clusters as Drivers of Sustainable Regional Economic Development? An Analysis of an Automotive Cluster from the Perspective of Firms' Role. Sustainability, 12(7), 2848.

Fomina, I. B., Kushnarenko, T. V., Tabakov, A. N., \& Jakovenko, V. V. (2020). Analysis of Clustering Processes in the Regions' Innovative Sustainable Development Formation. In Digital Future Economic Growth, Social Adaptation, and Technological Perspectives (pp.213-220). Springer, Cham.

Fornahl, D.,Heimer, T.,Campen, A.,Talmon-Gros, L. (2015). Cluster als Paradigma der Innovations politik - Eine erfolgreiche Anwendung von Theorie in der politischen Praxis?. Studien zum deutschen Innovations system Nr. 13-2015. 
Grabher, G. (1993). 'The weakness of strong ties: the lock-in of regional development in the Ruhr area' in Gernot Grabher (ed.), The Embedded Firm: On the Socio-economics of Interfirm, Relations. London: Routledge, pp.255-277.

Grashof, N., \& Fornahl, D. (2020). To be or not to be' located in a cluster? -A descriptive meta-analysis of the firm-specific cluster effect. Working Papers on Innovation and Space, 1.

Isaksen, A. and J. Karlsen. (2012). What is regional in regional clusters? The case of the globally oriented oil and gas cluster in Agder, Norway. Industry and Innovation 19(3): 249-263.

Kaiser, M.J. and A.G. Pulsipher. (2007). A review of the oil and gas sector in Kazakhstan" Energy Policy 35(2):1300-1314.

Kalhoro, M., I.B. Naqvi, Z.A. Memon, N.M. Jamali, S. Kalhoro, and S.A. Kalhoro. (2017). The Community Perception of CSR: A Case Study of Oil and Gas Industrial Clusters of District Dadu, Sindh, Pakistan. Lasbela, U. J.Sci.Techl., Vol. VI:303-308, ISSN 2306-8256.

Krugman, P., (1991). Geography and trade. Cambridge, MA: MIT Press.

Li, J., Webster, D., Cai, J., \& Muller, L. (2019). Innovation clusters revisited: On dimensions of agglomeration, institution, and built-environment. Sustainability, 11(12), 3338.

Loasby, B.J. (1999). Knowledge, Institutions and Evolution in Economics. London Routledge.

Lombardi, M. and F. Randelli. (2012). "The role of leading firms in the evolution of SMEs clusters: Evidence from the leather products cluster in Florence. In: Dipartimento di Scienze Economiche, Universitadegli Studi di Firenze, Working Paper N. 17/2012.

Mallick, S. (2017). Scientific Perspective on Sustainable Development Goals for Pakistan, A Scientific Journal of COMSATS - SCIENCE VISION Vol. 21 No. $1 \& 2$.

Marshall, A. (1920). Principles of Economics, 8th ed..London, Macmillan.

Maskell, P. (2001). Towards a Knowledge-based Theory of the Geographical Cluster. Industrial and Corporate Change 10 (4): 921-943.

Menzel, M.P. and D. Fornahl. (2007). Cluster life cycles-Dimensions and rationales of cluster development. Jena Economic Research Paper (2007076).

Menzel, M.P. and D. Fornahl. (2009). Cluster life cycles-dimensions and rationales of cluster evolution. Industrial and Corporate Change 19(1): 205-238.

Plyaskina, N. I., Kharitonova, V. N., \& Vizhina, I. A. (2017). Policy of regional authorities in establishing petrochemical clusters of Eastern Siberia and the Far East. Regional Research of Russia, 7(3), 225-236.

Porter, M. (2003). The economic performance of regions. Regional Studies 37(67):549-578. 
Porter, M.E. (1996). Competitive advantage, agglomeration economies, and regional policy. International Regional Science Review 19(1-2):85-90.

Porter, M.E. (1998). Clusters and the New Economics of Competition (Vol.76, No.6, pp.77-90). Boston: Harvard Business Review.

Porter, M.E. (2000). Location, competition, and economic development: Local clusters in a global economy. Economic Development Quarterly 14(1):1534.

Porter, M.E. (2007). Clusters and economic policy: Aligning public policy with the new economics of competition. ISC White Paper, November.

Porter, M.E. (2008). Competitive strategy: Techniques for analyzing industries and competitors. Simon and Schuster.

Porter, M.E. and C. Ketels. (2009). Clusters and industrial districts: common roots, different perspectives. A handbook of industrial districts, pp.172183.

Sandee, H. (1998). Promoting small-scale and cottage industry clusters in Indonesia. Small Enterprise Development 9(1):52-57.

Schmitz, H. and K. Nadvi. (1999). Clustering and industrialization: introduction. World Development 27(9): 1503-1514

St. John, C. H. and R. W. Pouder. (2006). Technology clusters versus industry clusters: Resources, networks and regional advantages. Growth and Change. 37: 141-17.

Tirmizi, S. T., \& Tirmizi, S. R. U. H. (2017). GIS based risk assessment of oil and gas infrastructure in Sindh, Pakistan. Environmental and Earth Sciences Research Journal, 4(3), 55-59. 